Vol. 11, n 1 | 2007

Varia

\title{
«The madness of party»: Sectarian homicide in Ireland, 1801-1850
}

\section{Richard McMahon}

\section{(2) OpenEdition \\ 1 Journals}

Édition électronique

URL : https://journals.openedition.org/chs/150

DOI : 10.4000/chs. 150

ISSN : 1663-4837

Éditeur

Librairie Droz

\section{Édition imprimée}

Date de publication : 1 juin 2007

Pagination : 83-112

ISBN : 978-2-600-01160-0

ISSN : $1422-0857$

\section{Référence électronique}

Richard McMahon, « «The madness of party»: Sectarian homicide in Ireland, 1801-1850 ", Crime, Histoire \& Sociétés / Crime, History \& Societies [En ligne], Vol. 11, n | 2007, mis en ligne le 01 juin 2010, consulté le 25 mars 2022. URL : http://journals.openedition.org/chs/150 ; DOI : https://doi.org/ 10.4000/chs. 150

Ce document a été généré automatiquement le 25 mars 2022.

(c) Droz 


\title{
«The madness of party»: Sectarian homicide in Ireland, 1801-1850
}

\author{
Richard McMahon
}

Such is... the madness of party that Mohammedans and Jews are not more adverse to each other, nor actuated by a more persecuting spirit than the opposing parties in this country ${ }^{2}$

\section{I}

1 The extent and nature of violent activity in Ireland in the first half of the nineteenth century constitutes an important, at times controversial, but as yet insufficiently researched area of study. There has, in fact, been little agreement on the role of violence in Ireland in this period. On the one hand, there are those who have viewed early nineteenth-century Ireland as a particularly violent place. This was certainly the view of many commentators of the time and is supported, to some degree at least, by the numerous studies of rural unrest in pre-Famine Ireland, which have demonstrated how violence and the threat of violence was utilized, mainly by agrarian secret societies, in order to uphold supposedly communal norms and to regulate socioeconomic conditions ${ }^{3}$. The extent of such unrest has, indeed, led one commentator, to conclude that early nineteenth-century Ireland was a remarkably violent country ${ }^{4}$. A number of historians have, however, challenged or at least qualified the view of Ireland in this period as a particularly violent society. Cormac ó Gráda, for instance, has argued that the belief in endemic violent criminality in pre-Famine Ireland was almost certainly exaggerated ${ }^{5}$. Similarly, David Fitzpatrick has suggested that Irish society at this time, in certain regions and for prolonged periods, was not endemically or abnormally violent ${ }^{6}$.

2 Commentary on the extent of sectarian violence in this period reflects, in some respects, these contrasting perspectives on the extent of violent activity. The dominant view among those who have commented on sectarian violence is that sectarian animosity was a significant and direct cause of violent conflict.For Kerby Miller, in the 
last quarter of the eighteenth century and the first half of the nineteenth, sectarian outrages frequently occurred throughout the island ${ }^{7}$. Sean Connolly has claimed that sectarian animosities were a source of recurrent fighting throughout this period principally though not exclusively [in the north of the country] $]^{8}$. J.S. Donnelly jr. speaks of a culture of popular violence born of economic crucifixion, sectarianism, and repression in the late eighteenth century that became increasingly prevalent in the nineteenth century 9 . More generally, Oliver MacDonagh has identified religious division as one of the primary sources of violence in Ireland ${ }^{10}$. Others have, however, challenged the notion of sectarian animosity as a major source of violent conflict. Donald Harman Akenson, for instance, has pointed out, in a study of nineteenth- and early twentieth-century Ireland, that the differences between Irish Catholics and Irish Protestants, though strongly held, were for the most part not violent. In many local and in myriad social situations, the two groups got on peaceably together, the surface amity being like the thin ice on a newly frozen pond ${ }^{11}$. Indeed, Akenson goes further suggesting that it was because of - not in spite of - the character of the two Irish belief systems, Protestant and Catholic, that the two tribal groups managed to coexist. In his view, both sides emphasized and, indeed, luxuriated in the small differences between them. This, in turn, provided a clear and uncomplicated world view that offered both comfort and stability to each community thereby lessening the need for violent conflict between them ${ }^{12}$.

What was the relationship between sectarian animosity and violent activity in Ireland in the first half of the nineteenth century? This article will explore this question through a quantitative and contextual analysis of the incidence of sectarian homicide ${ }^{13}$. While agreeing with Akenson that sectarian animosity was not a major cause of violent conflict, a somewhat different interpretation of the relationship between sectarianism and violence will be offered here. It will be argued that the relatively low rate of sectarian homicide evident in Ireland at this time was rooted less in the extenuation or exaggeration of religious difference but rather was a product of the complex interplay of wider forces and controls operating on and, more particularly, within both the Catholic and Protestant communities. This, it will be suggested, was not a particularly violent society or one in which violence was necessarily socially disruptive but rather one in which sectarian animosity and violent activity were clearly controlled.

\section{II}

4 To begin with, it is, perhaps, necessary to reflect on the context in which these cases arose. The roots of sectarian feeling in Ireland lie in the political and religious conflicts and controversies of the sixteenth and seventeenth centuries. This period witnessed the confirmation of British rule over the island of Ireland, the establishment of a Protestant, or more specifically Anglican, ruling elite in the country and the influx of considerable numbers of Protestant settlers, most notably into the northern province of Ulster ${ }^{14}$. The enactment of a series of penal laws in the late seventeenth and early eighteenth centuries also placed restrictions on the rights of the majority Catholic and minority Presbyterian populations and enshrined in law their exclusion from legal, civil and military offices ${ }^{15}$. The first half of the eighteenth century saw the consolidation of Anglican power within the country. From the 1760s onwards, however, there was a growing campaign for Catholic emancipation from the penal laws and the development of the Catholic question as a key feature in Irish political life ${ }^{16}$. There was 
also a growing critique both within some sections of the Anglican community and more particularly among Presbyterians of the existing political order ${ }^{17}$.

5 Such disenchantment found its clearest expression in the political upheavals of the 1790s, culminating in the 1798 Rebellion which saw, despite the avowed antisectarianism of many of those involved, an upsurge in sectarian animosity and violence which left Irish society more bitterly polarized than before. It also contributed, in the longer term, to a legacy of militant Catholic nationalism and Protestant loyalism in the country ${ }^{18}$. The latter being most clearly expressed in the form of the Orange Order, an oath-bound society dedicated to the maintenance of Protestant ascendancy in Ireland, and the former finding expression through organizations such as the Defenders and, later, the Ribbonmen ${ }^{19}$.

6 The first half of the nineteenth century, following the Act of Union ${ }^{20}$, saw an increase in these sectarian tensions in Ireland ${ }^{21}$. This rise in sectarian feeling was both reflected in and extenuated by a variety of different developments. The issue of Catholic emancipation came increasingly to dominate the political agenda in Ireland at this time. Although the distinct possibility or even expectation of Catholic emancipation had been raised before the Act of Union, it was thwarted in the early decades of the nineteenth century and was only granted under a considerable degree of popular and political pressure in $1829^{22}$. In the intervening period there was an often acrimonious campaign for emancipation. In particular, the highlighting of Catholic grievances by the Catholic Committee during the first two decades of the century and, perhaps more importantly, the emergence in the 1820 s of popular Catholic nationalism as a significant organized force in Irish political life, in the shape of the Catholic Association, served to emphasize sectarian divisions ${ }^{23}$. The 1820s, therefore, witnessed, as Connolly puts it, a sharp resurgence of sectarian hostility, affecting all levels of Irish society ${ }^{24}$.

7 Some of the activities undertaken at this time by the major church bodies in Ireland, Anglican, Catholic and Presbyterian, also seem to have increased tensions between the Catholic and Protestant communions. The renewed vigour, enthusiasm and organizational discipline of both the Catholic Church and the Church of Ireland served to heighten tension between them. The proselytizing activities of some members of the Church of Ireland and the consequent reaction of the Catholic Church also seem to have been a significant contributory factor in the rise of sectarian animosity ${ }^{25}$. The turn away by sizeable sections of the Presbyterian community in these decades from the more radical politics of the 1790s, which had incorporated a demand for Catholic emancipation, also served to put a strain on relationships with the majority Catholic population ${ }^{26}$. The payment of tithe by all denominations to support the minority Anglican Church, which led to disturbances, particularly in areas of the south of the country, in the early 1830s, also probably contributed to Catholic resentment towards the Anglican Church and, more specifically, its clergy ${ }^{27}$.

8 The authorities, both local and central, also contributed, at times, to the heightening of sectarian feeling. The Dublin administration certainly could, particularly in the early decades of the century, display a sectarian bias. Individuals within the administration were seen as acting, and, at times, certainly did act, favourably towards the Protestant side $^{28}$. The forces of law and order did not escape accusations of sectarian bias either. The magistracy was predominantly Protestant in composition and many individual magistrates were seen in the early decades of the century as being more than 
sympathetic to the Protestant cause. The yeomanry ${ }^{29}$ was also seen as having a pronounced sectarian dimension. According to Bartlett, the yeomanry at this time was often on the Protestant side, for the force was almost entirely a Protestant - and indeed, an Orange - on $e^{30}$.

9 There were efforts at reform particularly in the later decades of the period under review. 1822 saw the establishment of a countrywide police force as the primary means of law enforcement in the country ${ }^{31}$. The force, unlike the yeomanry, included a considerable number of Catholics within its rank and file ${ }^{32}$. This period also saw the introduction of professional or stipendiary magistrates, and a number of attempts to reform and revise the magistracy itself ${ }^{33}$. There were also attempts to control and limit the expression of party allegiance through a ban on party processions ${ }^{34}$. By the late 1830s the administration in Dublin, under a Whig/liberal government, was also more clearly sympathetic to Catholic claims ${ }^{35}$. Yet, despite these efforts at reform in later decades, the developments outlined above, almost certainly served to increase sectarian tension in Irish society in the first half of the nineteenth century.

III

10 To what extent did sectarian animosity give rise to acts of lethal violence? Any quantitative study of homicide must face the usual methodological difficulties inherent in such an exercise. There is always the possibility, if not probability, of a dark figure of criminal activity, i.e. those acts which do not come to the attention of or are not recorded by the authorities. It is, however, possible to counter this problem to some degree by using multiple sources. This study is based on police reports of homicide, court records and newspaper accounts of specific incidents and criminal trials. It includes all reported incidents which are identified as sectarian by the police and magistrates in their reports and also cases where sectarian animosity is explicit or can reasonably be implied as a key motivation of one or more of the parties involved based on evidence in the available sources. In the context of the period under review, the bulk of our quantitative data is drawn from the period 1835 to 1850 when police records are both more plentiful and reliable. It is possible, however, to draw on other sources for earlier decades. It should also be borne in mind that sectarian homicides tended to be public and involve members of opposing groups who were often willing to report and prosecute their opponents, which certainly renders the data more reliable than, say, data on incidents of domestic violence.

11 The following analysis is based on a limited national sample for Ireland between 1843 and 1845 , the only three years for which complete and reliable national data is available, and a more limited national sample for the Famine years, 1845-1850, as well as a more long-term study of four counties, Co. Armagh and Co. Fermanagh, in the north, and Queen's Co. and Co. Kilkenny, in the south of the country, between 1835 and 1850. The data gleaned from these samples, combined with some more qualitative evidence from the period before 1835, suggests that sectarian animosity was not a major cause of lethal violence or wider social unrest in this period ${ }^{36}$.

12 On a national level, between 1843 and 1845, there were seven reported cases of sectarian homicide accounting for a mere 1.67 per cent of all reported homicides. Indeed, three times as many reported homicides arose from sporting contests (twentyone cases accounting for 5.03 per cent of cases) than from sectarian conflict $^{37}$. The 
Famine years, 1845-50, did see an increase in the proportion of such homicides with sectarian cases accounting for 3.44 per cent of homicides, albeit based on a somewhat more limited sample, for the years 1847,1848 and $1849^{38}$. The higher percentage of incidents for these years is due to the inclusion in the figures of the somewhat exceptional Dolly's Brae incident in Co. Down on 12 July 1849. On this day, as a consequence of a confrontation between Orangemen and Ribbonmen six people were fatally injured ${ }^{39}$. This incident, however, was due more to the climate created after the failed rebellion of $1848^{40}$ than with the immediate conditions of the Famine ${ }^{41}$. Indeed, during those years when the impact of the Famine was at its height, 1847 and 1848, the incidence of sectarian homicide in the country seems to have been remarkably low ${ }^{42}$.

There was some regional disparity in the incidence of these cases. The highest number of cases occurred, perhaps unsurprisingly, in the north of the country where the population was more evenly divided between Catholic and Protestant groupings. This is reflected in the national data for 1843-1845 where three of the seven cases arose in the province of Ulster (north), two in Munster (south) and one each in Connacht (west) and Leinster (east). It is further emphasized in the sample drawn from the years 1847-1849, where eight of the nine cases occurred in Ulster and of these six were related to the incident at Dolly's Brae.

This regional difference is also evident in the figures from the more long-term study of four counties, Co. Armagh, Co. Fermanagh, Queen's Co. and Co. Kilkenny. These counties had somewhat different religious make-ups and varying reputations for sectarian violence. Armagh had a high proportion of Anglicans, mainly living in the north of the county, and Catholics, primarily in the south. There was also a small but not insubstantial Presbyterian population in the central areas of Armagh ${ }^{43}$. The county was the birth place of the Orange Order and that organization had a substantial presence in the county in the first half of the nineteenth century ${ }^{44}$. It was also generally regarded as the most sectarian and deeply-divided county in Ireland at this time. Neal Garnham, in his study of violence in eighteenth-century Ireland, describes Armagh as the nursery of sectarian conflict in Ireland ${ }^{45}$. There was, in fact, a considerable upsurge in sectarian conflict in the county in the late eighteenth century ${ }^{46}$. Co. Fermanagh also had a high proportion of both Anglicans and Catholics within its borders, with the former again mainly in the north of the county and the latter in the south ${ }^{47}$. The Orange Order was also quite prominent in Fermanagh and the county had a reputation, although not as pronounced as Co. Armagh, for sectarian conflict ${ }^{48}$. The presence of Protestants was less obvious in the southern counties. Of the two counties, Queen's Co. had the more substantial Protestant presence within its borders and a greater reputation for sectarian animosity ${ }^{49}$. The Orange Order also seems to have been more prominent in the county, especially in the mid-1830 ${ }^{50}$. Kilkenny had a relatively small Protestant population and the Orange Order seems to have been almost non-existent in the county ${ }^{51}$.

Table one: Sectarian homicides in four Irish counties

\begin{tabular}{|c|c|c|c|}
\hline Co. Armagh, 1835-1850 & Co. Fermanagh, 1811-1850* & Co. Kilkenny, 1835-1850 & $\begin{array}{c}\text { Queen's Co. } \\
\mathbf{1 8 3 5 - 1 8 5 0}\end{array}$ \\
\hline 9 & 11 & 0 & 1 \\
\hline
\end{tabular}




\begin{tabular}{|c|c|c|c|}
\hline 10 & 14.66 & 0 & 1.28 \\
\hline 0.24 & 0.19 & 0 & 0.04 \\
\hline
\end{tabular}

*. The more long-term study of Co. Fermanagh is due to the better newspaper coverage available for that county in this period.

15 As table one indicates there was a marked contrast in the number of sectarian homicides between the north and south of the country in this period. In Armagh between 1835 and 1850, there were nine times as many homicides arising from sectarian conflict as in Queen's Co.. In Fermanagh the incidence of such cases was also higher than those counties in the south.

We must, however, be aware that our sample does not include data from before 1835 for three of the four counties. In the one county where data is available, Co. Fermanagh, the evidence suggests that sectarian homicides were more common prior to 1835 . Of the eleven homicides reported eight occurred in the period prior to 1835 with most of these arising in the 1820s. The extent of the difference between pre- and post- 1835 should not, however, be exaggerated. Four of the eight homicides in Co. Fermanagh prior to 1835 arose from a single confrontation which occurred in 1829 and were related to particular tensions surrounding the passing of the Catholic Emancipation Act (1829) ${ }^{52}$. This year seems, in fact, to have been the highpoint for sectarian violence in Ireland in the first half of the nineteenth century ${ }^{53}$. Outside of this contentious period, however, the extent of serious sectarian violence was probably quite limited. According to Farrell, in the years between 1800 and 1820, outbreaks of sectarian violence were sporadic and small in scale, only emerging, to any great extent, between 1811 and $1814^{54}$.

Furthermore, the relatively low incidence of sectarian homicide also seems to reflect a low level of social unrest generally in both Armagh and Fermanagh. Table two outlines the responses of eighty-six men to the parliamentary commission survey in 1835 on the incidence of disturbances in their parishes since 1815.

18 This table indicates that there was little unrest in either county at this time. Fermanagh was, in fact, repeatedly praised throughout this period for its peaceful and stable state by the judges who presided at the assize court in the county. Addressing the Grand Jury, at the summer assize of 1844 , the judge congratulated them and the county at large, on the continued tranquility which had characterised the county for nearly half a century that he [had] known it, in travelling the circuit both as counsel and judge ${ }^{55}$.

Table two: Responses from Co. Armagh and Co. Fermanagh to inquiries by the 1835 poor law commission $^{56}$

\begin{tabular}{|c|c|c|c|c|c|c|c|}
\hline County & $\begin{array}{c}\text { Perfectly } \\
\text { tranquil }\end{array}$ & Tranquil & Peaceable & $\begin{array}{c}\text { Not } \\
\text { disturbed }\end{array}$ & $\begin{array}{c}\text { Occa- } \\
\text { sionally } \\
\text { disturbed }\end{array}$ & $\begin{array}{c}\text { Very much } \\
\text { disturbed }\end{array}$ & Total \\
\hline Armagh & 3 & 1 & 49 & 2 & 3 & 0 & 58 \\
\hline Fermanagh & 2 & 0 & 19 & 3 & 3 & 1 & 28 \\
\hline
\end{tabular}


Armagh also won praise from the judiciary for its peaceful state. For instance, in 1824, at the Armagh summer assize, the Hon. Justice Torrens remarked that in a county of such immense population, great trade, flourishing commercial intercourse, the state of the calendar denoted a degree of civilization not exceeded by any county in the Empire ${ }^{57}$.

The lack of sustained statistical evidence from before 1835 may be more significant in Queen's Co. and Co. Kilkenny as both suffered from severe rural unrest in the late $1820 \mathrm{~s}$ and early 1830s and had a far greater reputation for violence than their northern counterparts at that time. Table three outlines the responses of ninety-one men (mainly clergy and justices of the peace) to a parliamentary commission survey in 1835 on the incidence of disturbances in their parishes since 1815.

Table three: Responses from Co. Kilkenny and Queen's Co. to inquiries by the 1835 poor law commission $^{58}$

\begin{tabular}{|c|c|c|c|c|c|c|c|}
\hline County & $\begin{array}{c}\text { Perfectly } \\
\text { tranquil }\end{array}$ & Tranquil & Peaceable & $\begin{array}{c}\text { Not } \\
\text { disturbed }\end{array}$ & $\begin{array}{c}\text { Occa- } \\
\text { sionally } \\
\text { disturbed }\end{array}$ & $\begin{array}{c}\text { Very much } \\
\text { disturbed }\end{array}$ & Total \\
\hline Kilkenny & 0 & 0 & 12 & 0 & 31 & 2 & 45 \\
\hline $\begin{array}{c}\text { Queen's } \\
\text { Co. }\end{array}$ & 1 & 0 & 4 & 0 & 22 & 19 & 46 \\
\hline
\end{tabular}

21 Both counties, and particularly Queen's Co., seem to have experienced considerable social unrest in this period with many respondents citing the early 1830 s as a period of particular disturbance. Indeed, Queen's Co. had by 1833 become the most disturbed county in Ireland $d^{59}$. Moreover, a significant element of this unrest stemmed from the issue of the tithes to be paid to the Anglican Church. The period of tithe agitation in the early $1830 \mathrm{~s}$ did, in fact, produce a number of violent attacks on Protestants ${ }^{60}$.

Yet, even in the context of Co. Kilkenny where the tithe war originated in the early 1830s, a place where and a time when one might expect to find violent sectarian activity, violence, when it did occur, was directed more at the forces of law and order who enforced tithe collection rather than in sectarian hostility towards local Protestants ${ }^{61}$. Indeed, tithe did not invariably divide people along sectarian lines but could, in fact, bridge the gap. In Queen's Co., Catholic and Protestant farmers seem to have been as one in their refusal to pay tithe in the early $1830 \mathrm{~s}^{62}$. Thus, the tithe agitation does not seem to have led to any considerable upsurge in lethal sectarian violence. This finding is also consistent with McGrath's study of interdenominational relations in pre-Famine Tipperary, a county generally regarded as the most disturbed in Ireland in the pre-Famine period. He argues that it is doubtful if many murders can be attributed to intrinsic sectarianism at this time ${ }^{63}$. On the whole, it seems likely that, even before 1835, sectarian homicide was rare in both Queen's Co. and Co. Kilkenny which would seem to suggest, at the very least, that violent activity arising from sectarian animosity was clearly controlled within these areas.

It should, of course, be acknowledged that there is perhaps nothing unusual in the rare occurrence of homicide. Acts of lethal violence are usually rare and generally exceptional responses to wider social, economic and/or personal problems, tensions 
and grievances ${ }^{64}$. Yet, and perhaps of more significance, sectarian homicides constituted but a small proportion of all acts of lethal violence. Sectarian homicides were, in this sense, a rare manifestation of an already rare occurrence ${ }^{65}$. In Queen's Co., for instance, sectarian homicides accounted for only 1.26 per cent of cases. In the north, the proportion of sectarian cases was somewhat higher. In Fermanagh between 1835 and 1850, homicide cases arising from sectarian strife accounted for 9.37 per cent of reported homicides in the county and in Armagh the nine homicides arising from sectarian strife accounted for ten per cent of all reported homicides. Yet, even in the northern counties the proportion of sectarian homicides was still relatively low. In Armagh over four times, and in Fermanagh over three times, as many cases arose from personal and family disputes as from sectarian animosity ${ }^{66}$. This would suggest that when violence did arise sectarian animosity was not a particularly prominent cause or motivation for the protagonists. Thus, based on both the number of homicide cases and on some more qualitative evidence, sectarian animosity was not a major cause of lethal violence or wider social unrest in this period. This seems to be the case both for the country generally and in the northern counties such as Fermanagh and, particularly, Armagh which were most affected by sectarian strife.

It should be noted, however, that my figures do not include political homicides (which in an Irish context may have had sectarian overtones). There can be little doubt but that, as Hoppen has demonstrated, serious acts of lethal violence could arise from political contests and rivalries. For instance, in Carlow alone, in 1832, fourteen people were killed in a riot arising from the election of that year. Such incidents would seem to underline the considerable potential for violent political conflict in Ireland at this time $^{67}$.

Table four: The incidence of homicides arising from political disputes

\begin{tabular}{|l|l|l|l|l|l|l|}
\hline Cause & $\begin{array}{c}\text { Ireland } \\
1843-1845\end{array}$ & $\begin{array}{c}\text { Ireland } \\
1847-1849\end{array}$ & $\begin{array}{c}\text { Armagh } \\
1835-1850\end{array}$ & $\begin{array}{l}\text { Fermanagh } \\
1811-1850\end{array}$ & $\begin{array}{l}\text { Kilkenny } \\
1835-1850\end{array}$ & $\begin{array}{c}\text { Queen's } \\
\text { Co. } \\
1835-1850\end{array}$ \\
\hline $\begin{array}{l}\text { Homicides arising from } \\
\text { political disputes }\end{array}$ & 2 & 1 & 0 & 0 & 1 & 1 \\
\hline $\begin{array}{l}\text { Percentage of all } \\
\text { homicide cases }\end{array}$ & 0.47 & 0.38 & 0 & 0 & 0.8 & 1.28 \\
\hline Rate per 100,000 & 0.007 & 0.01 & 0 & 0 & 0.3 & 0.04 \\
\hline
\end{tabular}

Yet, lethal violence arising from political conflict must again be seen in context. The evidence from our samples certainly suggests that political rivalries were not, for the most part, a major cause of lethal violence at least. These figures are also consistent with Desmond McCabe's findings. McCabe has shown that only 0.5 per cent of homicides in Co. Mayo between 1823 and 1845 were rooted in political causes ${ }^{68}$. This would suggest that, although political tensions and contests could, at certain times, give rise to serious acts of violence, they were not a major cause of lethal violence particularly when compared to more personal or familial conflicts. Moreover, the addition of these political homicides to those arising more directly from sectarian 
animosity would not alter in any significant way the finding that lethal violence arising directly or indirectly from sectarian feeling was a relatively rare occurrence.

\section{IV}

In what circumstances, then, did sectarian animosity give rise to violent conflict and what forms did such violence take? The following study is based primarily on a number of sectarian homicides that took place in Co. Fermanagh between 1811 and 1850 and Co. Armagh between 1835 and 1850. In Armagh between 1835 and 1850 there were, as noted above, nine homicides that arose from seven different incidents, while in Fermanagh, over a forty-year period between 1811-50, there were eleven homicides arising from eight separate incidents.

Such incidents generally took three main forms: large-scale communal confrontations, disputes between groups and disputes between individuals. In Armagh, of the seven incidents recorded for the county between 1835 and 1850 one can be seen as a communal confrontation, two arose from disputes between rivals groups while the other four incidents seem to have been the product of arguments between individuals. In the Fermanagh sample, one case arose from a dispute between individuals, six incidents involved conflicts between groups while there was one large-scale communal confrontation.

There were generally three key aspects to these cases. First, they almost invariably and perhaps quite predictably involved an attempt by one side to assert itself over the other. Second, they show a willingness to respond to threats from the opposing side by resorting to acts of violence. Third, they reveal that violence or at least lethal violence was rarely premeditated but rather tended to emerge in the context of the specific situation in which the parties found themselves.

\section{Communal violence}

Large-scale confrontations usually coincided with the annual commemorations that took place on the twelfth of July to mark the success of William III over James II at the Battle of the Boyne in July 1690 . Such commemorations and the Orange processions, which often accompanied them, had, as Kinealy, points out, acquired a reputation for sectarian violence in this period ${ }^{69}$. The clearest example of such a confrontation in our sample occurred in Macken, Co. Fermanagh on Monday 13 July $1829^{70}$ when four Protestant men, Edward Scarlet, Robert Mealey, George Price, and James Robinson were killed in the so-called Macken fight.

The following account of that incident is primarily based on the evidence given by a total of fifty witnesses (twenty-four for the prosecution and twenty-six for the defence) over the course of three trials at the spring assize of Co. Fermanagh in $1830^{71}$. There are obviously conflicting accounts of what occurred at Macken between the case put forward by the prosecution and that put forward by the defence. There are also inconsistencies within both the prosecution and defence cases as to the precise timing of the events. Yet the accounts given are by no means mutually exclusive and it is possible to give an outline of the main events of the day even if the nature and sequence of such events are somewhat unclear or disputed. 
31 This incident occurred just three months after the Catholic Emancipation Act was passed in April 1829. This significant national political change also provided an opportunity for greater Catholic assertiveness on a local level. As Marianne Elliott has pointed out, while Catholic emancipation brought little immediate benefit to the average Catholic...it did wonders for him psychologically and from 1829 onwards Orange parades were challenged at every level $7^{72}$.

32 Some members of the Catholic community in Co. Fermanagh certainly saw July 1829 as an opportune moment to express their objections to Orange marches taking place and did so successfully. On the day in question, about 1500 men, a number of whom had weapons $^{73}$, gathered in the county to prevent, and if necessary actively resist, the occurrence of an Orange march. The police and a number of magistrates, including Lord Enniskillen who at this time was Deputy Grand Master of the Orangemen of Ireland, arrived on the scene. Enniskillen attempted to get the men to disperse ${ }^{74}$.

The Catholic grouping, however, pointed to a number of Orangemen who had assembled at a nearby house and declared that they would not move until they were satisfied the Orangemen would not march. Enniskillen then went to this house where the Orangemen said they were afraid they would be murdered but agreed to disperse if Lord Enniskillen wished them to. At this stage, another larger Orange party was seen marching from the direction of Belturbet. Enniskillen rode out and met this group who said they had heard the country was rising and were afraid of all being murdered. He, however, managed to convince them to turn around and return the way they came by telling them that the Catholics would disperse if the Orangemen did not march ${ }^{75}$. At this point, Lord Enniskillen returned to the Catholic group and again asked them to disperse. They, however, said they would not do so until a flag was removed from a nearby hill. This was done shortly afterwards when Enniskillen ordered a tenant of his and a policeman to remove the flag. When this was done Enniskillen eventually prevailed on the crowd to return to their homes. A section of the crowd went in the direction of Macken, and they had great shouting and cheering ${ }^{76}$.

This combination of a significant national political change and greater Catholic assertiveness on a local level served to heighten fears and insecurities among members of the Protestant community in the area. It also probably strengthened resolve, among some Protestants at least, to rise to the challenge laid down by the Catholics on this day. Both of these factors were evident that evening when a group of about thirty Orangemen and members of their families dined at the house of Edward Scarlet, a Protestant farmer and Orangeman. It was here that the decision to walk through Macken, a predominately Catholic area, was taken and a party consisting of around thirty men, six of whom were armed with guns and bayonets and a number of women and children left from Scarlet's house and proceeded in the direction of Macken ${ }^{77}$.

The precise reasons for this decision are, however, somewhat unclear. According to most of the prosecution witnesses at the trial arising from this incident, fears among the Orangemen were heightened when a report reached them that a number of Protestants had been waylaid and beaten on the highway at Macken by a number ofriotous and disorderly persons... ${ }^{78}$. It was then decided that two of the men dining in Scarlet's house, Thomas and George Thompson, would need an escort home and the others present would accompany them along the road.

36 This version of events was certainly accepted at the trial by judge and jury and is by no means implausible. There are, however, some doubts surrounding it. According to the 
crown solicitor for the north-west circuit, it was not clear whether the report that Protestants had been beaten was well founded or not ${ }^{79}$. At least one witness, James Armstrong, also admitted, under cross-examination, that it was not settled in the lodge at Scarlet's before the party left it to convey the Thompsons home ${ }^{80}$. The group that left Scarlet's house was also soon augmented by a second party of Orangemen, consisting of about 16 along the road, who joined them on the way to Macken and of which a further five or six were armed with guns and bayonets ${ }^{81}$. The fact that there was already an armed Orange party on the road going in the direction of Macken would seem to suggest that the escorting home of the Thompsons was not the sole motivation of those involved.

Just as Protestant fears had been raised by the Catholic gathering earlier in the day, the approach of a group of around fifty Protestants certainly raised fears among the Catholic community of Macken. Patrick McHugh, a defence witness, claimed that he was drinking in Widow Carron's public house when Mrs. Carron came to where witness was, and said there was a party coming to murder the people $e^{82}$. Michael McManus, seeing an armed Orange party approach his house and hearing them cheering each other to go on left his house along with his wife and family for fear of being killed ${ }^{83}$. A number of defence witnesses also indicated that the Orangemen acted in a provocative manner as they approached Macken. One witness Philip Flanagan, claimed that he heard shouts of No Pope - No Surrender. The above mentioned Mrs. Carron also heard shouts of No Pope, No Surrender, and somewhat incongruously No King coming from the Orangemen ${ }^{84}$.

As the Protestant party approached Macken they were met by Francis McBrien, a Catholic, who attempted to negotiate with both Edward Scarlet and Robert Mealy, both Protestants ${ }^{85}$. A large group of Catholics had also assembled on the hill at Macken at this time. According to Christopher Carson, a prosecution witness, Francis McBrien, desired witness's party to go home peacably ${ }^{86}$. Some agreement may have been reached at this stage as the Orange party began to retreat down the hill.

It was at this point, however, that conflict was to break out. According to the prosecution case, the Protestant party made its way peacefully down the hill. George Thompson, a prosecution witness, claimed, for instance, that the Orangemen did not say a word, nor do any thing as they made their retreat. A number of defence witnesses, however, claimed that at least some of the Orangemen taunted the Catholics from the foot of the hill. Philip Flanagan gave evidence that he saw the Orange party take off their hats, and call on the party on the hill to come down for cowardly dogs ${ }^{87}$. Whether provoked or not, a small group of Catholics (between fifteen and twenty people) did go down the hill in the direction of the Protestant party ${ }^{88}$. Before they reached them, however, two or three shots were fired from the Orange party as they continued their retreat from the hill.

A number of prosecution witnesses pointed out that these shots were fired into the air. John Quigley, for instance, claimed that the first two shots were fired in the air, when the Orange party had their faces towards Scarlet's... ${ }^{89}$. One of the shots, however, seems to have hit a Catholic, William Rooney, who was on the hill at the time. Rooney himself claimed that John Glass, a miller and member of the Protestant party, fired the shot at him deliberately without any provocation ${ }^{90}$. Whatever the intention, the firing of these shots was clearly a provocative ${ }^{91}$ gesture and it seems to have sparked off the general confrontation between the groups. At this point, a large group of Catholics came down the hill and attacked the Orangemen. A number of the Orangemen continued their retreat but others stayed and fought. The Orangemen were outnumbered and it was 
during this confrontation that Robert Mealy was killed after being stabbed with a pitchfork by one of the Catholic party and Edward Scarlet, James Robinson and George Price received the wounds that caused their deaths.

41 Similar circumstances surrounded the killing of John Boyle, a young Catholic man, by a gun-shot wound received in the course of a riot involving Orangemen and Catholics in Armagh in $1845^{92}$. This confrontation arose from an Orange procession on 12 July and it also followed a relatively significant national political development. The summer of 1845 was the first occasion on which Orange marches could legally take place in Ireland since 1832, following parliament's decision not to renew the Party Procession Act when it expired on 1 June 1845. This effectively allowed Orange marches to take place again after a thirteen-year prohibition.

42 It also provided the Orangemen with an opportunity to assert or re-assert their local strength. A procession consisting of around three hundred Orangemen left Armagh on the morning of 12 July 1845 for nearby Loughgall. A number of flags were on display, some of the men wore orange lilies and a number of party tunes such as Croppies lie down were also played ${ }^{93}$. The procession marched in good order to nearby Loughgall returning to Armagh city at around half past five that evening. As they did so they fired a number of shots. According to Anthony Coyle, who was employed to drive one of the cars at the front of the procession, there might have been beyond thirty or...more [shots] fired by persons in the procession on coming back to Armagh ${ }^{94}$.

Like Macken there was again an attempt, or at the very least a perceived attempt, by Orangemen to proceed towards a predominantly Catholic area. In this case, there were fears that the Orangemen would attempt to march towards Irish St., which was in a Catholic area of the city ${ }^{95}$. Similar to Macken the homicide in Armagh was also by no means planned but rather was triggered by events on the ground. Indeed, a relatively minor incident actually sparked off the confrontation. A man on horseback called William Montgomery was leading the Orange procession up Thomas St. when a number of small boys called out to him to play Garryowen". He replied Go to h_l; no "Garryowen" will be played here and he then rode up the street in pursuit of the children. One of the boys then threw a stone at the horse and Montgomery was reported to have said by heavens he would slay them like Philistines. As he pursued the children, however, his horse was caught hold of by a hostler called Tierney who turned the horse around and forced the man to return in the direction of the Orange procession while the children continued to throw stones at him ${ }^{97}$.

When Montgomery went back into the Orange crowd a shot was fired from the Orange party in the direction of Ogle Street, which runs perpendicular to Irish Street. By this time, a group of 40 or 50 Catholics had assembled at the head of Ogle Street. Stone throwing then began on both sides and shots continued to be fired. Barnes, the petty sessions clerk, claimed that there were at least fifty shots fired in the course of the riot. The firing came initially from the Orange party but after a time the Catholic group returned fire ${ }^{98}$.

The police did attempt to intervene. Sub-inspector Kelly, met the Orangemen as they moved up Ogle street. He stood in their way extending his sword in one direction, and [his] arm in the other, and said: 'Oh, my God, boys, surely you're not coming in this direction. Go back - go back'. The Orangemen, however, presented two or three pistols and fired one quite close to [Kelly]... in the direction of Ogle St. and the stone throwing and shooting continued on both sides. The extent of the stone throwing from Ogle Street in the direction of the 
Orangemen seems to have forced them to move back along the street. As they did so, however, they broke the windows of local businesses and continued to fire shots ${ }^{99}$. It was one of these shots that hit John Boyle who had been throwing stones at the Orangemen from Ogle Street. He died as a consequence of the wound the next day. The riot itself was not brought under control until the local magistracy ${ }^{100}$ and more particularly the army arrived on the scene. The military marched up Dobbin St. and eventually brought the situation under control but by then the damage had been done.

\section{Group violence}

Incidents of group violence also involved the attempt by one side to challenge, or assert itself over, the other. This is particularly evident in the attempts to achieve dominance over a particular occasion such as a fair. Bartlett has pointed out that the classic occasions for demonstrations of Catholic strength in numbers were the fairs and markets which were springing up or being revived around the country in the early nineteenth century ${ }^{101}$. There were also, as Bartlett points out, considerable fears among Protestants about such demonstrations of strength and also a willingness among some to respond to such Catholic assertiveness with violence ${ }^{102}$. This is evident in Fermanagh in March 1824 when a Protestant, Robert Ingram, was killed at the fair of Ederney. This incident was the culmination of a number of violent clashes at the fair between Catholics and Protestants in which the latter had come out the worse for wear ${ }^{103}$. On the day in question, a number of Protestants decided that they needed to resist this Catholic aggression. As one of them put it, from the treatment the Protestants received, he thought it right to put [the Catholics] down...[and] he thought some measure should be resorted to prevent them rioting in Ederney as the fair had become more a mart for assassination than for commerce $^{104}$.

Other occasions for group violence included race meetings. In Fermanagh in 1835, a William Lang, was killed in a riot that followed the victory of a horse called Protestant Boy at the Enniskillen races. This was, in fact, somewhat of an empty victory as the horse ran the course unopposed after another horse (presumably representing the Catholic interest) was withdrawn from the race ${ }^{105}$. Group conflicts could also take place in or around pubs and involve assertions of strength or superiority over seemingly minor matters. In Fermanagh in February 1841, George Latimer, a Protestant, died from injuries he received in a dispute in a pub between a group of Protestant men and a number of Catholics over a pipe ${ }^{106}$.

Often times no particular issue was at stake in these encounters but rather a more general challenge was issued. In Armagh in April 1835, Hugh Donnelly was killed in a fight at a fair at Drumcree, near Portadown. This incident seems to have been sparked off when Donnelly's son, Hugh junior, cursed a number of Protestant men, calling one an Orange rascal and another a turncoat rascal and daring them to fight him. When a fight broke out, Hugh's father and a number of men came to his aid and Hugh senior was heard to declare that there was not a twelve stone Orangeman in the fair he could not beat ${ }^{107}$.

In certain circumstances, those involved in these confrontations were also often prepared for, or even expected to engage in, violent activity. For instance, in Fermanagh in 1824, a pre-arranged boxing match or challenge fight between two men, Lunny, a Catholic, and Kenny, a Protestant, was due to take place on the island of Inishmore. The challenge fight, according to one witness, was about the party quarrels. 
Supporters of both men and curious onlookers gathered from about six o'clock in the morning on the day. Some seem to have come to see the fight, and shew[sic] fair play, others, however, brought weapons with them. One defence witness, in fact, revealed that he heard the challenge spoken of the evening before, the boys were to go there [and] every one of them had cudgels... ${ }^{108}$.

More sophisticated preparations could also be resorted to. Randall Kernan esq., a Catholic barrister on the north-west circuit, claimed in 1835 that it was constant practice in the morning of the fair, for the yeomen to lodge their arms in a particular place or depot; then if a row took place in the evening, or a riot, they fought for some time with sticks, and after this the yeomen generally went for their arms and fired upon the people assembled at the fair ${ }^{109}$. He also recounted an incident which occurred in Co. Fermanagh in 1811 where a Catholic man was killed in a party fight between Orangemen and a group of Catholics. According to Kernan, they commenced fighting with sticks at an early hour; the Catholics had the best of the battle; the Orange yeomen retreated and got their arms, and then fired upon the people, which was the common way of concluding the fights in those days ${ }^{110}$.

51 Events of a similar character are evident at the fair of Ederney in Co. Fermanagh in 1824 at which Robert Ingram was killed. On the fair day, a number of riots took place in the late morning and early afternoon during which several Protestants were beaten. In response to these beatings, a number of Protestants formed a guard, made up of about twelve or fourteen men that included the deceased, Robert Ingram. This guard was formed at about three or four o'clock in the day at a place called Drumkeen where the men armed themselves. From Drumkeen the guard marched back to Ederney with guns and bayonets screwed on, over their shoulders ready to confront the opposing side ${ }^{111}$.

Yet, while violence may have been expected there is also little evidence of premeditated killings in these incidents. In the case in Ederney, a number of Catholics took offence at the actions of the Protestant party and gathered together and began to throw stones at the guard. The guard then took up a position at the house of an innkeeper called Henry Tiernan and the group of Catholics gathered around them and threw stones at the house one of which hit Ingram on the head and fractured his skull $^{112}$. These homicides, in fact, generally emerged in the context of a general group fight. This is clearly evident in the abovementioned killing in 1842 of George Latimer, who was hit on the head with a pair of tongs in the course of a general affray from the effects of which he died six or seven weeks later. In the case on Inishmore, William McCreery, a Protestant, was killed during a riot that broke out before the pre-arranged challenge fight could take place ${ }^{113}$. This pattern is also consistent with that found in riots that occurred in Belfast in the 1830s and 40s. Catherine Hirst, in her study of sectarianism in nineteenth-century Belfast, reveals how... riots in the early to mid nineteenth century were... remarkable for the low number of fatalities. It would also seem to confirm her suggestion that this may have been due to the fact that rioters in Belfast may also have followed an unwritten code of conduct which, in turn, had its roots in earlier sectarian conflicts in rural Ulster ${ }^{114}$.

\section{Violence between individuals}

There were also cases that were confined to individuals who attempted to assert themselves over others. In some cases, no particular issue was at stake but rather the incident revolved around a challenge stemming from a more general sectarian 
animosity. This is clearly evident in the killing of the two brothers, John and Michael Henderson, by Philip Fitzpatrick at Lurgan on 20 May $1848^{115}$. This was, in terms of numbers killed, the most serious sectarian incident in Co. Armagh over the entire sixteen-year period. It was probably also, relative to the other cases at least, the most premeditated of all the homicides in our entire sample. On the night in question, both Michael and John Henderson had been drinking with four other men in a public house called McGeown's in Lurgan. When they left the pub that evening, after having drunk $a$ pint of whiskey, a quart of beer and two glasses of cordial they walked out on to Back Lane. It was here that they encountered Philip Fitzpatrick who was shouting, and exclaimed that he could beat ever a papist in the lane. Michael Henderson, who, according to one witness, was intoxicated, took umbrage at this and engaged in a fight with Fitzpatrick. They were, however, separated by a Patrick Gallery, who had been drinking with the Hendersons, but who declared that the man who would strike "Phil" would strike him. This put a stop to the fight between Michael and Philip. At this point, however, John Henderson intervened and exchanged four or five blows with Fitzpatrick. It was in the course of this fight that Fitzpatrick stabbed John Henderson through the heart with a butcher's knife which he had, in fact, borrowed some hours earlier. He then seems to have approached Michael Henderson again and, although the latter pleaded with him a number of times that he had, already done enough, Fitzpatrick stabbed and killed him as well. After killing both brothers he was heard to declare I'm the boy can lay them by ${ }^{116}$.

There were also cases where individuals responded to an insult or challenge with lethal violence. In Fermanagh in February 1835, John Armstrong, a Protestant, was suspected of the killing of Roger O'Neill, a Catholic. This case was believed by the police to have arisen in consequence of $[a]$ difference in religion ${ }^{117}$. On the day in question, John Armstrong, a Protestant, was beaten on the road five miles outside Enniskillen by a number of people returning from a funeral. Following the beating, Armstrong ran to the house of a relation and there armed himself with a spade and, along with a friend of his called Robert Armstrong, went along the road to seek revenge. On the road, both men came across a group of Catholics returning from the funeral none of whom, as it appeared on the inquest, had any concern in the [earlier] abuse of John Armstrong ${ }^{118}$. Among this group was Roger O'Neill. Armstrong seems to have singled him out and without any provocation whatever hit him on the head with the spade handle from the effects of which O'Neill died a few days later ${ }^{119}$.

It is likely also that in many of these cases a personal dispute intermingled with wider sectarian tensions within the community to give rise to homicidal violence. This is evident in the killing of William Flynn near Newtownhamilton, Co. Armagh, in October 1847 for which Joseph and John Thompson were indicted at the spring assize of 1848.Flynn, a Catholic, was returning home one night with a number of people along a public road from a fair when Alexander, Joseph and John Thompson, all Protestants, overtook him on the road. At this point, Flynn left the group he was with and went up to Joseph Thompson and asked if he wanted for company? Thompson replied that he did not as he was in a hurry home. Flynn then asked what if he were made wait, and pushed Thompson into a ditch. Following this Thompson went up the road to the house of a man called James Henry. There were a number of people in the house including two policemen. Thompson told those present what had occurred and one of the policemen told him that he could bring Flynn before the court of petty sessions for the assault but Thompson declared he would be revenged of him. Mrs. Henry, who was in the house at the 
time, chided him for the words he made use of in the house, and added that he would not be able to beat any person ${ }^{120}$.

At this point, a number of people were heard passing the house when Thompson rushed out and the police followed him. The police then heard a voice at the gate of Henry's house declare to William Flynn, are you as good a man now as you were to-night before. Flynn simply replied I am. There was a confrontation, at this stage, the exact nature of which is, however, difficult to ascertain as a number of witnesses claimed that due to the darkness and the nature of the weather they were unable to see exactly what was happening. It is clear, however, that during the course of the fight Flynn was stabbed in the heart and died shortly afterwards ${ }^{121}$.

According to Joshua Magee, the county coroner, the locality in which this offence occurred, near Newtownhamilton, was a mountainous area in which the people are... divided into two hostile factions Orange \& Catholic. He pointed out also that tensions in the locality had been greatly increased in the last twelve months since a Catholic named McEllherron lost his life in an affray in [Newtownhamilton], \& since that period a deep revengeful feeling prevails \& when the people meet they view each other somewhat in the same light, that two hostile armies would ${ }^{122}$.

\section{V}

58 What do these cases reveal about the relationship between sectarian animosity and violent activity in Ireland at this time? These homicides, whether arising from communal, group or individual conflicts expose real and significant sectarian tensions and offer clear support to the position that sectarian animosity was a direct cause of violent activity at this time. In particular, the incidents of communal violence demonstrate the ability of sectarian feeling to mobilize large numbers of people, both Catholic and Protestant, in a way that few other issues could, and to provoke violent conflicts, which seem to reveal pervasive and real sectarian divisions, that are difficult, if not impossible, to dismiss as unrepresentative of attitudes in the wider culture. Yet, as was demonstrated earlier in this article, such animosity rarely gave rise to serious or lethal violent conflict. Such cases as did arise constituted but a small proportion of all acts of lethal violence; and based on more qualitative evidence from the poor law commission it seems that sectarian conflict did not give rise to widespread unrest at this time. Thus, if we assume that widespread and deep-rooted sectarian animosity should give rise to high rates of serious violence, there seems to be an apparent inconsistency between the quantitative data on sectarian homicide and the contextual analysis of particular incidents. Is it possible to explain this apparent inconsistency?

It may be that in many instances and in many areas the conditions for the emergence of violent conflict were not present. Throughout this article the importance of two factors has been noted in incidents of lethal violence. First, the attempt by one side to assert itself over the other and, second, a willingness to respond to a challenge from the opposing side by resorting to acts of violence. In the south of the country there can be little doubt of Catholic self-assertion in this period. It can clearly be found, for instance, in the mass demonstrations of the 1820s in favour of Catholic emancipation and in the anti-tithe demonstrations of the early $1830 \mathrm{~s}^{123}$. Yet, there were few enough serious or lethal acts of violence arising from sectarian animosity. This may have been due to reluctance among Protestants to rise to such challenges, as it would have placed them 
in a dangerous and invidious position, perhaps, leaving them exposed to further reprisals. Many in the south may, in fact, have chosen the route of migration to the north of the country or emigration to North America as an altogether safer option ${ }^{124}$. The relative absence of sectarian violence should not lead us, therefore, to underestimate the strength and extent of sectarian animosity in the south of the country. It seems, however, that the conditions for the expression of such animosity in acts of lethal violence were limited.

In the north too, segregated communities and the dominance by one religious grouping over another within specific localities may have served to lessen the likelihood of confrontation. James Denham, esq., a magistrate in Co. Fermanagh, informed the 1835 poor law commission that the parish of Cleenish was quiet because it was a Protestant parish [and] the Roman Catholics dare not disturb the country as in the south of Ireland ${ }^{125}$. Another magistrate in the county, William Darcy esq., also reported that the parish of Derryvollan was perfectly peaceable and pointed out that the parishioners [were] chiefly Protestants ${ }^{126}$. In such instances, the risk and fear of reprisal against the minority group may have outweighed their willingness to re-act to the assertion of dominance by the majority. Emigration, as Donnelly and Clark have pointed out, may also have served to lessen the extent of unrest generally in the north ${ }^{127}$.

61 Yet, while local dominance, segregation and wider forces such as emigration may have contributed to the low rates of lethal sectarian conflict they do not of themselves wholly explain them. In some respects, issues of local dominance simply raise further questions about the role of violence at this time. For instance, why didn't local dominance translate into persecution of the minority through acts of lethal violence? It is important also not to overemphasize the degree to which these were mutually exclusive communities. There was still ample opportunity for both communities to interact in the course of their daily routine, not to mention at fairs and markets ${ }^{128}$. Moreover, while emigration may have served to lessen the extent of social unrest it does not of itself explain the low rates of sectarian violence. It might be expected, for instance, that those who stayed behind were those who were most committed to staying and meeting any challenge to their community or religious identity. Moreover, there was, as noted, a considerable movement of Protestants into Ulster at this time from southern areas of the country, which may have contributed to rather than diminished the extent of sectarian animosity in the province. This would seem to suggest that there were other forces at work in the containment of violent sectarian conflict.

62 Another key factor may be the effectiveness of outside controls at this time. The ban on party processions between 1832 and 1845 may, for instance, have limited the opportunity for confrontations between the two communities. Yet, while this might partly explain the low rate of homicides arising from communal confrontations it does little to explain the low rate of incidents involving group and individual confrontations. Even a cursory examination of the court records of the time also reveals that the reaction to the imposition of the ban, among at least some members of the Protestant community, was often to continue with the processions in defiance of the law.

This period, of course, also saw the introduction of a national and centrally controlled police force in Ireland. It may be that the increasing role of the police in patrolling fairs and other large social gatherings may have served to inhibit the extent and frequency of violence. For instance, in Fermanagh in 1835, Sir Frederic Stovin reported that a 
fight was prevented at the Enniskillen races due to a display of force by the military and a large party of police on the day ${ }^{129}$. Yet, the role of the police in imposing outside control should not be exaggerated. The participants in a number of these cases seem to have been quite willing to ignore the police. This is evident on a communal level in the actions of the Orangemen in the shooting of Boyle in Armagh in 1845 and, on an individual level, in the actions of Thompson in ignoring the advice of the police in the same county in 1848. Moreover, in the above case in Fermanagh, although the police prevented a confrontation at the race meeting, a riot did break out following a subsequent meeting, perhaps indicating that the police could postpone but not always wholly prevent sectarian violence. Indeed, the presence of a large number of police did not always prevent a serious clash rather it could serve to aggravate the situation. For instance, there was a considerable police presence at the most serious incident of sectarian violence in this entire period, the killings at Dolly's Brae in Co. Down in 1849. The actions of the police on this day may have served to aid rather than inhibit violent activity ${ }^{130}$. This is not to suggest that the police were wholly ineffective in controlling sectarian violence, but rather that their effectiveness depended less on the display of force and more on whether the parties involved were willing to cede to their authority. In this sense, the display of force was probably a necessary but not always a sufficient condition for the police to maintain order.

A more effective control on the extent of violence may have been the role of local magistrates and prominent figures within these areas who could exert an influence over both sides of the community. This is evident in the role of Lord Enniskillen on the morning of the Macken fight, where his intervention helped to defuse a large-scale confrontation. There were also attempts, following the end of the ban on party processions in 1845 , by members of the local Protestant gentry to discourage Orange marches in the north of the country ${ }^{131}$. Efforts were also undertaken that year by leading figures within the Repeal movement and the clergy to encourage Catholics not to respond to any provocation arising from Orange marches. Thomas Steele, a prominent figure in the Repeal movement and a close associate of Daniel O'Connell, toured the north of Ireland prior to the marching season in 1845 and distributed 20,000 copies of an address calling on Catholics not to respond to any provocation arising from Orange processions ${ }^{132}$.

65 Yet, while figures such as Lord Enniskillen could play a useful role in brokering a settlement between rival groups, it is also clear that such influence was by no means total. There were certainly incidents where the advice of local notables was ignored. For instance, in the Inishmore fight in Co. Fermanagh in 1824 an attempt to prevent a confrontation by a local land agent, William Armstrong, failed. The actions of local magistrates could also serve to aggravate the situation. In the case of the killing of Lang in Fermanagh in 1835, the group of Protestants involved had originally been detained by the police and their weapons taken from them. Within a short period of time, however, they had been released on the instructions of a local magistrate and given back their weapons. Shortly after this, the fatal encounter in which Lang lost his life occurred $^{133}$. The efforts of political figures such Thomas Steele, however wellintentioned, may also have served more to raise suspicions within sections of the Protestant community than to lessen the likelihood of conflict ${ }^{134}$.

66 It is more likely that the low rate of lethal sectarian violence was due more to conditions and attitudes within these communities than simply the effectiveness of 
external controls upon them. There was probably a practical consideration within the communities themselves of the need to maintain stability and a realization of the inherent dangers and difficulties, both on an individual and communal level, in committing such acts as it might spark off a more thorough or large-scale confrontation. There may also have been a wider but not wholly unrelated consideration that lethal violence was simply not an appropriate response to sectarian animosity. In particular, unprovoked sectarian violence was probably not considered legitimate. It is notable, for instance, that, with the possible exception of Fitzpatrick, none of these cases seem to have been planned attempts to kill a member of the other community. When someone was killed, it seems, to have been as a result of injuries sustained in the course of a fight rather than a deliberate or premeditated decision to kill. This is also reflected in the fact that in the majority of cases those accused of homicides arising from sectarian conflict were either convicted on the lesser charge of manslaughter or, indeed, acquitted. This is all the more extraordinary when one considers that lethal weapons, in particular firearms, seem to have featured prominently in a number of cases. These were, it seems, communities in which a sense of religious difference and sectarian hostility intermingled, interacted and ultimately competed with considerations of local stability and ideas of what constituted legitimate violence.

There were, of course, situations where sectarianism overcame considerations of the need for peaceful co-existence within localities and concepts of legitimate violence. This is most evident in cases where individuals, such as Philip Fitzpatrick, broke ranks and indulged in extreme sectarian violence. Such occasions were, however, exceedingly rare and unrepresentative ${ }^{135}$. It is also evident at times of political change or instability, such as the passing of Catholic emancipation in 1829. Indeed, there can be little doubt of the connection between political instability and violent activity, and it is, perhaps, no coincidence that elections in nineteenth-century Ireland could also witness particular outbursts of serious violent conflict ${ }^{136}$. Yet, even here it depended more on the contingencies of particular situations rather than premeditated decisions to engage in acts of lethal violence. Indeed, it is probable that this reflects the degree to which violence was controlled and limited - rarely extending to homicide as a response to sectarian animosity or, indeed, political rivalry.

Violence was more likely to be carried out in a controlled manner and within the context of unwritten rules of appropriate action which may actually have served to enhance rather than disrupt communal stability by simultaneously expressing but also limiting the divisiveness of sectarian animosity. Similarly, the use of parades or processions in order to express religious (and political) identity, while provocative, also probably served to channel and restrict the assertion of religious identity in a relatively secure and controlled manner, although by no means a risk-free one.

Finally, it is necessary to reflect more directly on the role of religious identity and its relationship to violent activity. There can be little doubt that both Catholic and Protestant religious identities generated a considerable degree of sectarian animosity in this period and that such animosity could also lead, albeit rarely, to acts of lethal violence. Could it also be the case, as Akenson has suggested, that the character of both religious outlooks and the hostility they showed towards each other also served to lessen and control violent conflict? This is, to say the least, a dubious claim. It amounts, in strict sense, to a circular argument by claiming that Catholics and Protestants 
managed to coexist as Catholics and Protestants because they were Protestants and Catholics. Even to claim that by accentuating the small differences between each other they managed to coexist seems a dubious and, ultimately, untestable proposition. Surely, one could equally argue that if they had tried to lessen the significance of these differences it would have led to a more peaceful coexistence. A more likely explanation is that religious identity was itself bound up in and infused with competing considerations of sectarian hostility, community stability and concepts of legitimate violence. In this sense, the relatively low rate of sectarian homicide evident in Ireland at this time was rooted less in the extenuation or exaggeration of religious difference, but rather was a product of the complex interplay of competing considerations of religious identity, community and ideas of what constituted legitimate action. Such interaction ultimately underpinned the relationship between sectarian animosity and violent activity.

Of course, more work needs to be done on both the causes and dynamics of sectarian violence and, in particular, how it was contained and limited over the course of this period. More localized and in-depth studies of particular counties would also be helpful. This article has merely offered a preliminary sketch of such activity. Yet, based on a study of homicide at least, it seems safe to conclude that considerations of local circumstance and wider concepts of legitimate violence meant that while sectarian animosity was a real and pervasive force in Irish society in the early nineteenth century this did not necessarily make it a particularly violent place or one in which violence was necessarily socially disruptive. It was rather a society in which the extent of both sectarian animosity and violent activity was very clearly controlled within both the Catholic and Protestant communities. The picture that emerges, therefore, is not so much of a people bound by or in the thrall of the madness of party but rather communities that lived, however imperfectly, with the legacy of their history.

\section{BIBLIOGRAPHIE}

Akenson, D.H., The Church of Ireland: ecclesiastical reform and revolution, 1800-1885, New Haven and London, Yale University Press, 1971.

Akenson, D.H., Small differences: Irish Catholics and Irish Protestants, 1815-1922: an international perspective, Dublin, Gill and Macmillan, 1991.

Bartlett, T., Select documents 38: Defenders and Defenderism in 1795, Irish Historical Studies, 1985, xxiv, no. 95, pp. 373-394.

Bartlett, T., The fall and rise of the Irish nation: the Catholic question, 1690-1830, Dublin, Gill and Macmillan, 1992.

Bardon, J., A history of Ulster, Belfast, Blackstaff Press, 1992.

Beames, M., Peasants and power: the Whiteboy movements and their control in pre-Famine Ireland, The Harvest Press, Brighton, 1983. 
Blackstock, A.F., 'A dangerous species of ally': Orangeism and the Irish yeomanry, Irish Historical Studies, 1997, xxx, no. 119, pp. 393-407.

Blackstock, A.F., An ascendancy army: the Irish yeomanry, 1796-1834, Dublin, Four Courts Press, 1998. Broeker, G., Rural disorder and police reform in Ireland, 1812-36, London, Routledge and Keegan Paul, 1970.

Canny, N., Making Ireland British, 1580-1650, Oxford, Oxford University Press, 2001.

Clark, S., Social origins of the Irish land war, Princeton, Princeton University Press, 1979.

Clark, S., Donnelly J.S., jr., (Eds.), Irish peasants: violence and political unrest, Manchester, Manchester University Press, 1983.

Conley, C.A., Melancholy accidents: the meaning of violence in post-Famine Ireland, Lanham, Lexington Books, 1999.

Connolly, S.J., Mass politics and sectarian conflict in Vaughan, W.E. (Ed.), A new history of Ireland, $v$. Ireland under the union, I. 1801-70, Oxford, Oxford University Press, 1989, pp. 74-107.

Connolly, S.J., Priests and people in pre-Famine Ireland, 1780-1845, Dublin, Four Courts Press, 2001, second edition.

Crossman, V., Politics, law and order in nineteenth-century Ireland, Dublin, Gill and Macmillan, 1996.

Cullen, L.M., The political structure of the Defenders in Dickson, D., Gough, H., Ireland and the French Revolution, Dublin, Irish Academic Press, 1990, pp. 117-138.

Curtin, N., The United Irishmen: popular politics in Ulster and Dublin, 1791-1798, Oxford, Oxford University Press, 1994.

Dickson, D., Keogh D., Whelan, K., (Eds.), The United Irishmen: republicanism, radicalism and rebellion, Dublin, Lilliput Press, 1993.

Donnelly, J.S., jr., The Rightboy movement, 1785-8, Studia Hibernica, 1977-1978, 17-18, pp. 120-202.

Donnelly, J.S., jr., Pastorini and Captain Rock: millenarianism and sectarianism in the Rockite movement of 1821-4 in Clark, S., Donnelly J.S., jr., (Eds.), Irish peasants: violence and political unrest, Manchester, Manchester University Press, 1983, pp. 102-139.

Donnelly, J.S., jr., Sectarianism in 1798 and in Catholic nationalist memory in Geary, L. (Ed.), Rebellion and Remembrance in Modern Ireland, Dublin, Four Courts Press, 2001, pp. 15-37.

Dunne, T., Popular ballads, revolutionary rhetoric and politicization in Dickson, D., Gough, H. (Eds.), Ireland and the French Revolution, Dublin, Irish Academic Press, 1990, pp. 139-155.

Dunne, T, Rebellions: memoir, memory and 1798, Dublin, The Lilliput Press, 2004.

Elliott, M., Partners in revolution: the United Irishmen and France, New Haven, Yale University Press, 1982.

Elliott, M., The Catholics of Ulster: a history, London, Penguin Books, 2000.

Elliott, M., Religious polarization and sectarianism in the Ulster rebellion in Bartlett, T., Dickson, D., Keogh, D., Whelan, K., (Eds.), 1798: a bicentenary perspective, Dublin, Four Courts Press, 2003, pp. 279-297.

Farrell, Sean, Rituals and riots: sectarian violence and political culture in Ulster, 1784-1886, Kentucky, University Press of Kentucky, 2000. 
Fitzpatrick, D., Class, family and rural unrest in nineteenth century Ireland in Drudy, P.J. (Ed.), Ireland: Land, politics and people, Cambridge, Cambridge University Press, 1982, pp. 37-75.

Fitzpatrick, D., Unrest in rural Ireland, Irish Economic and Social History, 1985, xii, pp. 98-105.

Garvin, T., Defenders, Ribbonmen and others: underground political networks in pre-Famine Ireland, Past and Present, 1982, 96, pp. 133-155.

Garnham, N., How violent was eighteenth century Ireland? Irish Historical Studies, 1997, xxx, 119, pp. 377-392.

Geoghegan, P.M., The Irish Act of Union: a study in high politics, 1798-1801, Dublin, Gill and Macmillan, 1999.

Gibbon, P., The origins of Ulster unionism: the formation of popular Protestant politics and ideology in nineteenth-century Ireland,Manchester, Manchester University Press, 1975.

Gibbons, S.R., Captain Rock in the Queen's Co. in Nolan, W., Lane, P. (Eds.), Laois: history and society: interdisciplinary essays on the history of an Irish county, Dublin, Geography Publications, 1999, pp. 487-512.

Haddick-Flynn, K., Orangeism: the making of a tradition, Dublin, Wolfhound Press, 1999.

Hirst, C., Religion, politics and violence in nineteenth century Belfast: the Pound and Sandy Row, Dublin, Four Courts Press, 2002.

Hoppen, K.T., Elections, politics and society in Ireland, 1832-1885, Oxford, Oxford University Press, 1984.

Hoppen, K.T., 'Grammars of electoral violence in nineteenth-century England and Ireland' in The English Historical Review,1994, 109, 432, pp. 597-620.

Jenkins, B., Era of emancipation: British government of Ireland 1812-1830, Kingston and Montreal, McGill-Queen's University Press, 1988.

Kelly, J., A study of Ribbonism in Co. Leitrim in 1841 in Augusteijn, J., Lyons, M.A., McMahon, D., (Eds.), Irish history: a research yearbook No.2, Dublin, Four Courts Press, 2003, pp. 32-42.

Kinealy, C., A right to march? The conflict at Dolly's Brae in Boyce, D. G., Swift, R., (Eds.), Problems and perspectives in Irish history since 1800: essays in honour of Patrick Buckland, Dublin, Four Courts Press, 2004, pp. 54-79.

Kingon, S., Ulster opposition to Catholic Emancipation, 1828-9, Irish Historical Studies, 2004, xxxiv, 134, pp. 137-55.

Lee, J.J., Ribbonmen in Williams, T.D. (Ed.), Secret societies in Ireland, Dublin, Gill and Macmillan, 1973, pp. 26-35.

Lenihan, P., 1690: Battle of the Boyne, Stroud, Tempus Publishing, 2003.

MacDonagh, O., States of mind: a study of Anglo-Irish conflict 1780-1980, London, Allen and Unwin, 1983.

Maddox, N.P., A melancholy record: the story of the nineteenth-century Irish party processions acts, The Irish Jurist, 2004, xxxxix, new series, pp. 243-274.

McCabe, D.J., Law, conflict and social order: County Mayo, 1820-45, Ph.D. thesis, University College Dublin, 1991. 
McGrath, T.G., Interdenominational relations in pre-Famine Tipperary in Nolan, W. (Ed.), Tipperary: history and society: interdisciplinary essays on the history of an Irish county, Dublin, Geography Publications, 1985, pp. 256-287.

McMahon, R., 'Homicide, the courts and popular culture in pre-Famine and Famine Ireland', Ph.D. thesis, University College Dublin, 2006.

Miller, D.W., The Armagh troubles, 1784-95 in Clark, S., Donnelly J.S., jr., (Eds.), Irish peasants: violence and political unrest, Manchester, Manchester University Press, 1983, pp. 155-191.

Miller, D.W., The origins of the Orange Order in Co. Armagh in Hughes A.J., Nolan W. (Eds.), Armagh: history and society: interdisciplinary essays on the history of an Irish county, Dublin, Geography Publications, 2001, pp. 583-605.

Miller, K.A., The lost world of Andrew Johnston: sectarianism, social conflict and cultural change in southern Ireland during the pre-Famine era in Donnelly, J.S., jr., Miller, K.A., (Eds.), Irish popular culture, Dublin, Irish Academic Press, 1999, pp. 222-241.

Monkkonen, E., New standards for historical homicide research, Crime, Histoire \& Sociétés / Crime, History \& Societies,2001, 5, 2, pp. 5-26.

Ó Gráda, C., Ireland: a new economic history, 1880-1939, Oxford, Oxford University Press, 1994.

O'Hanrahan, M., The tithe war in Co. Kilkenny, 1830-1834 in Nolan, W., Whelan, K. (Eds.), Kilkenny: history and society: interdisciplinary essays on the history of an Irish county, Dublin, Geography Publications, 1990, pp. 481-505.

Ó Muirí, R., 'The Orangemen, Repealers and the shooting of John Boyle in Armagh, 12 July 1845', Seanchas Ard Mhaca, 1985, 11, 2, pp. 435-529.

Ó Tuathaigh, M.A.G., Thomas Drummond and the government of Ireland, 1835-1841, Galway, O'Donnell lecture series, 1978.

Palmer, S.H., Police and protest in England and Ireland, 1780-1850, Cambridge, Cambridge University Press, 1988.

Senior, H., Orangeism in Ireland and Britain, 1790-1836, London, Routledge and Keagan Paul, 1966. Spierenburg, P., Long-term trends in homicide: theoretical reflections and Dutch evidence, fifteenth to twentieth centuries in Johnson, E. A., Monkkonen, E. H., (Eds.), The civilization of crime: violence in town and country since the middle ages, Urbana, University of Illinois Press, 1996, pp. 63-105.

Vaughan, W.E., Ireland c.1870 in Vaughan W.E. (Ed.), A new history of Ireland, v. Ireland under the union, I. 1801-70, Oxford, Oxford University Press, 1989, pp. 726-801.

Whelan, I., The bible war in Ireland: the 'Second Reformation' and the polarization of Protestant-Catholic relations, 1800-40, Dublin, Lilliput Press, 2005.

Whelan, K., The tree of liberty: radicalism, Catholicism and the construction of Irish identity, 1760-1830, Cork, Cork University Press, 1996.

Whelan, K., Introduction to section III in Bartlett, T., Dickson, D., Keogh, D., Whelan, K., (Eds.) 1798: a bicentenary perspective, Dublin, Four Courts Press, 2003, pp. 189-194.

Wilson, J., Orangeism in 1798 in Bartlett, T., Dickson, D., Keogh, D., Whelan, K., (Eds.) 1798: a bicentenary perspective, Dublin, Four Courts Press, 2003, pp. 345-362.

Wright, F., Two land on one soil: Ulster politics before Home Rule, Dublin, Gill and MacMillan, 1996. 
Zimmerman, G.D., Songs of Irish rebellion: political street ballads and rebel songs, 1780-1900, Dublin, Allen Figgis, 1967.

\section{Reference works}

The Waterloo directory of Irish newspapers and periodicals, 1800-1900, phase II (Ontario, 1986).

\section{NOTES}

2. Mr. McCartney, K.C., in stating the case at a trial for murder at the Armagh spring assize of 1824. Belfast Newsletter, 16 March 1824.

3. There is an extensive body of work on rural unrest in the first half of the nineteenth century in Ireland, for example, see Clark, Donnelly (1983); Beames (1983).

4. Clark (1979, p. 66).

5. Ó Gráda (1994, p. 332).

6. Fitzpatrick (1985, p. 100). For a more general discussion of violence in pre-Famine and Famine Ireland, see Mc Mahon (2006).

7. Miller (1999, p. 223).

8. Connolly (2001, p. 208).

9. Donnelly (1977-1978, p. 202).

10. MacDonagh (1983, p. 71).

11. Akenson (1991, p. 4).

12. Ibid., pp. 147-149.

13. The study of sectarian homicide cannot, of course, offer a complete or definitive account of sectarian violence. It can, however, offer an insight into key aspects of such violent activity. The reasons for this are three-fold. First, as Monkkonen (2001, p. 6) points out, homicide is undoubtedly a significant form of violence, which is worthy of study in its own right and without which any study of violence would be incomplete. Second, while a study of homicide may not reveal the levels of violent activity in a given society, it can aid in discerning the difference between a society in which the extent and nature of violence might be carefully limited and controlled and one in which such controls are substantially weaker or even non-existent. Third, these homicides provide a manageable, coherent and reasonably reliable sample of cases, which can provide an insight into wider patterns of sectarian violence at this time. For a discussion of the study of homicide as a means of understanding the wider role of violence in society, see Spierenburg (1996).

14. These settlers were mainly Anglicans and Presbyterians from England and Scotland. For an account of the policy and practice surrounding this settlement, see Canny (2001).

15. The actual operation of these laws has been the topic of some debate. For an overview, see Bartlett (1992).

16. For an overview of the role of the 'Catholic question' in this period, see Bartlett (1992).

17. The formation of the United Irishmen was the clearest manifestation of this disaffection. Initially a body that sought parliamentary reform, the United Irishmen developed in the course of the 1790s into an organization dedicated to the establishment of an Irish republic and the breaking of the connection with England. It also had the avowed aim of uniting all Irishmen regardless of religious persuasion. For an analysis of the role of the United Irishmen, see, among others, Elliott (1982); Dickson et al. (1993); Curtin (1994). 
18. Elliott (2003, p. 279). There are a number of different perspectives and considerable debate on the role and nature of sectarianism in the 1798 rebellion, see, among others, Dunne (1990; 2004), Whelan (1996) and Donnelly (2001).

19. For an account of the role of the Orange Order in the 1790s, see Senior (1966); Miller (2001); Wilson (2003). For the first half of the nineteenth century, see Senior (1966). For a more general account of the Orange Order, see Haddick-Flynn (1999). On the Defenders, see, among others, Bartlett (1985); Cullen (1990) and on the Ribbonmen, see Lee (1973); Garvin (1982); Kelly (2003).

20. An act for the union of Great Britain and Ireland ( $40 \mathrm{Geo} .3$ c. 38 and $40 \mathrm{Geo} .3$, c. 38 [Ire.]). This act created the United Kingdom of Great Britain and Ireland. It marked the end of the Irish parliament in Dublin and the election, for the first time, of Irish MPs to Westminster. This union was the preferred option for the maintenance of stability within Ireland among many in the British government in the aftermath of the 1798 rebellion. For an account of the political context in which the act was passed, see Geoghegan (1999).

21. According to Thomas Bartlett (1992, p. 273)... sectarian feeling in Ireland remained at a high level, indeed, almost certainly increased in the post-Union period.

22. An act for the relief of His Majesty's Roman Catholic subjects (10 Geo. 4, c. 7). The act removed all but a few of the remaining disabilities imposed on Catholics in Britain and Ireland. As a result, Catholics were eligible for all offices of state, except for that of Regent, Lord Chancellor of England or Ireland and Lord Lieutenant of Ireland.

23. For an account of the background to the introduction of the act, see Jenkins (1988); Connolly (1989); Bartlett (1992) and Kingon (2004). The impact of sectarian animosity on a popular level can also be seen in the appearance of Pastorini's prophecies in southern areas of the country in the early 1820s. These prophecies predicted the destruction of Protestantism in 1825. For an account of the impact of these prophecies, see Donnelly (1983).

24. Connolly (1989, p. 74).

25. For an overview, see Connolly (1989); Bartlett (1992). See also Akenson (1971, chapter two) and Whelan (2005).

26. Bardon (1992, pp. 250-252).

27. For an account of the impact of tithe agitation on a county level, see McGrath (1985); O’Hanrahan (1990).

28. For examples, see Bartlett (1992, p. 321).

29. The Irish yeomanry was established by statute in 1796 (37 Geo. III, c. 2). This body was a voluntary, part-time military force...for local law and order duties with the potential for military service during invasion or insurrection, Blackstock (1997, p.393). It was disbanded in 1834. See also Blackstock (1998).

30. Bartlett (1992, p. 322).

31. See Broeker (1970); Palmer (1988).

32. By 1833 Catholics accounted for thirty-six per cent of the rank and file of the Irish constabulary. Palmer (1988, p. 348). It should be noted, however, that, although not as obviously dominated by Protestants as the yeomanry, the force still encountered accusations of sectarian bias. This was particularly the case in Ulster and in the early years of its operation. See Palmer (1988, p. 346).

33. For an account of law and order policy in this period, see Crossman (1996).

34. In August 1832 parliament passed An act to restrain for five years, in certain cases, party processions in Ireland ( 2 \& 3 Will. 4, c. 118). This was renewed in 1838 by an act to continue for five years, and from thence until the end of the then next session of parliament, An act of the second and third years of the reign of His late Majesty, to restrain for five years, in certain cases, party processions in Ireland (1 \& 2 Vic., c. 34). In August 1844, parliament passed An act to continue until the first day of June one thousand eight hundred and forty-five an act of the second and third years of His late Majesty, for restraining for five years in certain cases, party processions in Ireland (7 \& 8 Vic., c. 63). This act lifted 
the ban on party processions in Ireland but an act of 1850 re-imposed the ban. An act to restrain party processions in Ireland (13 Vic., c. 2). See also Maddox (2004).

35. See Ó Tuathaigh (1978).

36. For a breakdown of the causes of homicide in Ireland in this period and for a discussion of the method of classification for individual cases, see McMahon (2006, appendix one).

37. This is based on a total of 417 cases reported by the police throughout the country between January 1843 and December 1845. Chief Secretary's office, constabulary returns, monthly returns of outrages, 1843-1845, National Archives of Ireland (NAI), 3/7/2. This finding is also consistent with that for late nineteenth-century Ireland where sectarian homicide only accounted for 2.6 per cent of reported homicides in the period, 1866-1892. See Conley (1999, pp. 173-174).

38. This is based on a total of 261 cases reported by the police for the following months (a) 1847 March, April, July, August, October, December; (b) 1848 - February, August, October, November, December; (c) 1849 - July, August, November. Chief Secretary's office, constabulary returns, monthly returns of outrages, 1847-1849, NAI, 3/7/2.

39. For an account of this incident, see Kinealy (2004). It should also be noted that the total number of deaths which occurred as a result of the conflict at Dolly's Brae is somewhat unclear, see Kinealy (2004, p. 55).

40. This was a very small-scale rebellion that occurred in late July 1848 and which ended after a short skirmish with police at a farmhouse in Ballingarry, Co. Tipperary, in which two insurgents were killed. The rebellion was led by an organization called Young Ireland, a small group of romantic nationalists, who like the United Irishmen before them, adopted a non-sectarian stance and included both Catholics and Protestants within their ranks.

41. Kinealy's account does not see the Famine as a significant influence on the events of that day. 42. In the sampled months for 1847 and 1848 sectarian homicides accounted for only 0.94 per cent of reported homicides.

43. For an account of the denominational make-up of Co. Armagh, see Miller (2001, pp. 583-589).

44. According to evidence given before the select committee on Orange lodges in 1835 there were over two hundred Orange lodges in Armagh at that time. Report from the select committee appointed to inquire into the nature, character, extent and tendency of Orange lodges, associations, or societies in Ireland, with the minutes of evidence, and appendix,H.C. 1835 (377), xv,p. 113 (hereafter cited as select committee on Orange lodges, 1835).

45. See Garnham (1997, p. 392).

46. For a discussion of the development of sectarian conflict in late eighteenth-century Armagh, see, among others, Gibbon (1975); Miller (1983); Cullen (1990); Whelan (1996); Wright (1996); Miller (2001).

47. Fermanagh and Armagh were quite distinctive in that they were, as Whelan points out, the only counties where Anglicans were not heavily outnumbered by Catholics and Presbyterians. According to Whelan, this created the social base for a hegemonic landed class and a populist loyalism that was not possible elsewhere. See Whelan (2003, pp. 192-193).

48. It was claimed that there were also over two hundred Orange lodges in Co. Fermanagh in the mid-1830s. Select committee on Orange lodges, 1835, p. 113.

49. According to Gibbons (1999, p. 491), the county had a larger than usual proportion of Protestants for a county in the south of the country. Actual estimates of the proportion of Protestants in the county, however, varied widely from one-in-four to one-in-twelve. He also points out that there was a deepening of sectarian animosities [in the county] in the eighteen-twenties.

50. It was reported before the select committee in 1835 that there was an increase in the number of Orange lodges in the county in the mid-1830s. Select committee on Orange lodges, 1835, pp. 198-200.

51. According to the evidence before the select committee in 1835 there were no Orange lodges in Co. Kilkenny at that time. Select committee on Orange lodges, 1835, p. 113. 
52. This case will be discussed in detail below.

53. Farrell (2000, pp. 96-99).

54. Farrell (2000, p. 99).

55. Enniskillen Chronicle and Erne Packet, 18 July 1844.

56. Poor inquiry (Ireland): appendix (E) containing baronial examinations relative to food, cottages and cabins, clothing and furniture, pawnbroking and savings' banks, drinking and supplement containing answers to questions 13 to 22 circulated by the commissioners, H.C. 1836, xxxii, [37], 1 (hereafter cited as poor law commission, appendix e).

57. Northern Whig, 12 August 1824.

58. Poor law commission, appendix e.

59. Gibbons (1999, p. 503).

60. For examples, see McGrath (1985).

61. See O'Hanrahan (1990).

62. Gibbons (1999, p. 499). Even in Armagh, both Catholics and Protestants came together to oppose tithe in an organization called the Tommy Downshire's boys. See Blackstock (1998, p. 255). This coming together of Protestants and Catholics in the one movement was, Blackstock argues, perhaps the exception that proved the rule.

63. McGrath (1985, p. 273).

64. It is safe to assume that aside from these lethal acts of sectarian violence there was a considerably higher number of non-lethal confrontations arising from sectarian animosity.

65. Assuming that around five per cent of homicides arose, between 1841 and 1850, from sectarian animosity (this would in itself be a generous estimate) the rate of sectarian homicide in the country as a whole would be 0.098 per 100,000 or less than 1 per $1,000,000$ inhabitants per annum. For a more general account of homicide rates, which were by no means unusually high, in Ireland at this time, see McMahon (2006, chapter one).

66. The role of violence in personal and family disputes in nineteenth-century Ireland has not received the attention it deserves. For some notable exceptions, see Conley (1999); McCabe (1991); Fitzpatrick (1982). Such disputes are also discussed in my Ph.D. thesis, see, in particular, chapters two and three.

67. For a discussion of electoral violence, see Hoppen (1994; 1984, pp. 388-408).

68. McCabe (1991, p. 82).

69. Kinealy (2004, p. 57). For an account of the Battle of the Boyne itself, see Lenihan (2003).

70. The traditional Orange commemorations were held on 13 July this year because the twelfth fell on a Sunday.

71. The main sources employed in my account are the reports of the trials in the Enniskillen Chronicle and Erne Packet, 25 March, 1 April, 8 April and 15 April 1830. This paper is described by the Waterloo Directory (1986) as being both Protestant and conservative. Although it was undoubtedly very sympathetic towards the Protestant position in its reporting, at the time of these trials the paper was, in fact, owned by a Catholic. Randall Kernan, a barrister from Enniskillen, also referred to the paper as a milk and water paper; it is neither the one thing nor the other...[the] articles are as frequently Orange as they are Catholic. The third report of the select committee appointed to inquire into the nature, character, extent and tendency of orange lodges, associations or societies in Ireland, 1835 (476), xvi, p. 72 (hereafter cited as third report on Orange lodges, 1835). My account of the incident also draws on information given to magistrates by witnesses, the report of the crown solicitor on the incident and the reports of the trials included in the third report of the select committee on Orange lodges in 1835.

72. Elliott (2000, p. 348). There were, in fact, a number of violent confrontations throughout Ulster in the summer of 1829, see Bardon (1992, p. 247) and Farrell (2000, pp. 96-99).

73. According to one witness, Montgomery Armstrong esq., they were armed with long pitchforks, pikes newly fabricated, loys, bayonets and scythes on sticks. Another witness, Lord Enniskillen, 
claimed that they had bayonets on poles, pikes, pistols, fleshforks, \& c., there were a few muskets..., Enniskillen Chronicle and Erne Packet, 25 March 1830.

74. Ibid. Lord Enniskillen addressed the crowd, declaring: Good God, boys! What are you about, what brought you here, for God's sake go away. In reply, he was told that the group wouldnot allow the Orangemen to walk. Enniskillen then gave assurances to the crowd that he would not allow them to walk, and begged the people to go home.

75. Ibid.

76. Ibid.

77. Third report on Orange lodges, 1835, app. g, p. 216.

78. Ibid.

79. Ibid.

80. Enniskillen Chronicle and Erne Packet,15 April 1830.

81. Third report on Orange lodges, 1835, app. g, p. 216.

82. Enniskillen Chronicle and Erne Packet,25 March 1830.

83. Ibid.

84. Enniskillen Chronicle and Erne Packet, 1 April 1830. The shouting of No King may have reflected a certain disenchantment with the monarch, George IV, for signing the Catholic relief Act in April 1829.

85. McBrien was well placed to carry out this negotiation as he had been born and bred in Ballymenone where many of the Orangemen had come from. He had only moved to Macken seven weeks prior to this incident and both he and his family were also said to have been always on good terms with the Orangemen..., Ibid.

86. Enniskillen Chronicle and Erne Packet, 25 March 1830.

87. Ibid.

88. They may or may not have been responding to Francis McBrien who waved his hat in the air at this point. There seems to have been some confusion as to whether this was to stop the group or to encourage them to come down the hill. The jury seems to have accepted the former explanation as McBrien was acquitted at his subsequent trial.

89. Enniskillen Chronicle and Erne Packet, 15 April 1830.

90. Third report on Orange lodges, 1835, app. g, p. 246.

91. James Armstrong, a prosecution witness, was clearly angry at those who fired the shots. According to his evidence at the trial he was beside the men that fired, and asked were they mad to do so and they attacked as they were..., Enniskillen Chronicle and Erne Packet, 1 April 1830.

92. The following account is based on the evidence given by seventeen witnesses at the coroner's inquest into the case as reported in the Armagh Guardian, 22 July 1845. An account of this incident and transcriptions of the inquest and subsequent trials may also be found in ó Muirí (1985).

93. This tune came to prominence in the late eighteenth century, particularly after the 1798 rebellion, when it was adopted by the Orangemen as an accompaniment for marching. There are many texts accompanying this tune, which generally celebrate the suppression of the rebellion in 1798. For examples, see Zimmerman (1967, pp. 307-310).

94. Armagh Guardian, 22 July 1845.

95. William Barnes, the clerk of the petty sessions, approached John Kitson, who rode in one of four horse-drawn jaunting cars at the front of the procession, and said to him Johnny, I hope you don't intend going through Irish street...the town is in peace and quietness at present, and by going there it will cause disturbance. Kitson denied that he would march to Irish St. but claimed that he would march along Thomas St. in the direction of Irish St. but would turn down Dobbin St., before he reached the Catholic area of the town. It is not clear, and, indeed, Barnes himself was unsure, whether or not Kitson would turn down Dobbin St. as he had indicated or continue through Thomas St. and Ogle St. to Irish St. It is evident, however, that at least some of the Orangemen had resolved to march to Irish St.. Patrick Duffy, a car-driver, who had been employed for the day 
by an Orangeman called Stoops, claimed that the latter instructed him to drive to Irish St. on their return to the city. Duffy claimed, however, that he objected, stating that he would not wish to go to Irish street. He was reluctant to go there because during the day two or three young chaps, who were dressed, and with the procession, cried 'To hell with the Pope' and [he] knew from that, if they went to Irish-street there would be a disturbance. According to Duffy, Stoops replied to his objection by stating Go on - don't be afraid - we will gain the day. Whatever the precise intentions of the Orangemen the decision to march in the direction of Irish St. brought matters to a head.

96. This song has a less explicitly sectarian dimension to it than Croppies lie down although, as the above incident indicates, it was clearly identified with the Catholic side. The text of the song, in fact, celebrates the joys of drinking and fighting. It was also adopted by Irish regiments within the British army and, later in the nineteenth century, by Irishmen serving in the United States army.

97. Armagh Guardian, 22 July 1845.

98. Ibid., Barnes declared that there were about 20 shots fired before he heard any shots from the direction of the Ogle-street party [the Catholics].

99. Sub-inspector Kelly estimated that there were from 416 to 420 panes of glass broken by the Orangemen along the street.

100. The response of the magistracy seems to have been quite tardy. The confrontation was in process for three quarters of an hour before they arrived on the scene. This seems to have been due to the fact that they were serving on the county grand jury at the time.

101. Bartlett (1992, p. 315).

102. Ibid., p. 316. See also Farrell (2000, p. 76).

103. According to one witness, Protestants found it dangerous to go to [the fairs in Ederney]. Enniskillen Chronicle and Erne Packet, 12 August 1824.

104. Ibid.

105. Enniskillen Chronicle and Erne Packet, 30 July 1835 and 10 March 1836.

106. Disputes over items such as pipes and tobacco seem to have been a common enough feature of violent confrontations in Ireland in the nineteenth century, see Conley (1999, p. 26). In this case, Latimer had borrowed a pipe from the owner of the pub and had given it to another Protestant man called Morton who refused to give it up. Morton, in fact, put [the pipe] in his pocket, and said there was no puppy in the house would take it from him. A Catholic called James Alwell made repeated efforts to retrieve the pipe but to no avail. He eventually confronted Morton with a stick and demanded the pipe from Morton three times but on each occasion the latter refused to give it to him. Alwell then hit him over the head with a stick and a number of people entered the room in support of Alwell. This, in turn, led to a general affray in which Latimer was killed. Enniskillen Chronicle and Erne Packet, 10 March 1842.

107. Belfast Newsletter, 31 July 1835.

108. Enniskillen Chronicle and Erne Packet, 19 August 1824.

109. Third report on Orange lodges, 1835, pp. 75-76.

110. Third report on Orange lodges, 1835, p. 75. See also Belfast Newsletter,20 March 1812.

111. Enniskillen Chronicle and Erne Packet, 12 August 1824.

112. Ibid.

113. Enniskillen Chronicle and Erne Packet, 19 August 1824.

114. Hirst (2002, pp. 80-81).

115. Armagh Guardian, 24 July 1848. A third man died as a consequence of lockjaw after being wounded in the thumb by Fitzpatrick. Armagh Guardian, 17 July 1848.

116. Armagh Guardian, 24 July 1848.

117. NAI, official papers, $1835 / 352$.

118. Enniskillen Chronicle and Erne Packet, 12 February 1835.

119. NAI, official papers, $1835 / 352$. 
120. Armagh Guardian, 6 March 1848.

121. Ibid.

122. NAI, Co. Armagh, outrage papers, $1847 / 303$.

123. See McGrath (1985) and O'Hanrahan (1990).

124. There seems to have been a considerable movement of Protestants from the south of Ireland in this period. See Miller (1999, p. 223). Miller points out that the hemorrhage of southern Irish Protestants [in the pre-Famine period] both resulted from and greatly contributed to the rise of middleclass Catholic political and economic ascendancy in those counties...

125. Poor law commission, appendix e, p. 351.

126. Ibid, p. 352.

127. Clark, Donnelly (1983, p. 150).

128. It is striking how some of the cases in our sample reveal co-operation and sometimes friendship between individual Catholics and Protestants within particular localities as well as sectarian animosity. In the case on the island of Innishmore in Co. Fermanagh, Kenny and Lunny both lived on the island, which, according to a local land agent, William Armstrong, contained a number of inhabitants... of different religious persuasions; [who had] lived till lately upon very amicable terms, save some trifling bickering betimes. Enniskillen Chronicle and Erne Packet, 19 August 1824. The evidence relating to the Macken fight also reveals some ties of friendship and co-operation on a local level. It was, for instance, pointed out by Edward Scarlet, son of one of the deceased, that Pat Montgomery, one of the accused, used to be dining in his house when steward of Mr. Nixon. John Glass, an Orangeman and a key prosecution witness, pointed out that he knew Francis McBrien, one of the accused, for a long time, and was on friendly terms with him. Enniskillen Chronicle and Erne Packet, 25 March 1830 and 1 April 1830. This would, in some respects, also seem to be consistent with the view of interdenominational relations in the north at this time put forward by Elliott. She suggests that while Catholics and Protestants viewed each other across a sectarian divide, friendships were still formed and there was a degree of interdependence on both sides. See Elliott (2000, ch. 10). See also Akenson (1991); Vaughan (1989, p. 745).

129. Select committee on Orange lodges, 1835, p. 326.

130. See Kinealy (2004).

131. Ó Muirí (1985, pp. 452-460).

132. Ibid. (1985, pp. 443-450).

133. Select committee on Orange lodges, 1835, p. 326.

134. Some within the Protestant community certainly saw Steele's efforts more as an act provocation than conciliation. See ó Muirí (1985, pp. 454-457).

135. Fitzpatrick was portrayed in the local press as very much of an outsider and was said to be known in the area as lieing Phil. He had been tried on four occasions previous to this. In 1838 he was convicted for destroying the walls of the Lurgan Bridewell, in 1842 and again in 1844 he was charged but acquitted, at the Lurgan quarter sessions, of exposing his person and in 1844 he was convicted of stealing $£ 1$ and sentenced to six months in prison at hard labour. Questions were also raised as to whether or not he was a Protestant. When he had been committed to goal on previous occasions, he had told the turnkey that he was a Catholic. At the time of his trial for murder, he claimed, however, that he was always a Protestant and had only said he was a Catholic to vex the deputy governor of the prison. The Armagh Guardian maintained, however, that he was only a Protestant through marriage and that he was originally a Catholic from Co. Cavan. Whatever the truth of the matter, it is clear that the Armagh Guardian, a Protestant newspaper, was keen to distance Fitzpatrick, who they described as a very bad character, commonly called a knacker, from the Protestant faith. See the Armagh Guardian,22 May, 24 July and 14 August 1848.

136. Farrell too has noted the relationship between periods of particular political crisis and outbreaks of sectarian violence, see generally Farrell (2000, chapters two, three and four). 


\section{RÉSUMÉS}

Cet article explore les relations entre sectarisme et violence en Irlande dans la première moitié du XIX siècle, à travers l'examen d'homicides sectaires. Il comporte une étude quantitative des incidents de ce type au niveau régional et national, ainsi qu'une analyse du contexte de la violence sectaire létale, au niveau de la communauté, du groupe et de l'individu. Ces incidents révèlent de réelles et significatives tensions sectaires au sein de la société irlandaise, quoique celles-ci ne donnèrent lieu que rarement à des conflits létaux. Selon l'auteur, pour comprendre cette situation, il faut prendre en compte simultanément l'hostilité sectaire, la stabilité locale et les conceptions de la violence légitime présentes dans les deux communautés, catholique et protestante, à cette époque.

This article seeks to explore the relationship between sectarianism and violence in Ireland in the first half of the nineteenth century through an examination of sectarian homicides. This will involve a quantitative study of incidents of sectarian homicide on a national and regional level, as well as a contextual analysis of lethal sectarian violence on a communal, group and individual basis. These incidents reveal real and significant sectarian tensions within Irish society yet such tensions rarely gave rise to lethal violent conflict. The key to understanding this situation, it will be argued, lies in a recognition of the competing considerations of sectarian hostility, local stability and concepts of legitimate violence within both the Catholic and Protestant communities in Ireland at this time.

\section{AUTEUR}

\section{RICHARD MCMAHON}

Centre for the Study of Human Settlement and Historical Change, National University of Ireland, Galway, richardmcmahon@ireland.com

Richard McMahon is the recipient of the first postgraduate studentship from the Irish Legal History Society under the auspices of which he completed a Ph.D. on Homicide, the courts and popular culture in pre-Famine and Famine Ireland in the School of Law at University College Dublin. $\mathrm{He}$ is the author of a number of articles on Irish legal history and is currently editing a volume of essays entitled Crime, law and popular culture in Europe 1500-1900. His research interests lie in the history of violence and the legal and criminal justice history of modern Ireland. The author would like to thank Mr. John Cronin, Dr. Mary Harris, Dr. John Moulden, Dr. Lesa Ní Mhunghaile and Professor Nicholas Canny for their assistance on aspects of this article. I alone am responsible for errors. This article was written while the author was based at the Moore Institute for Research in the Humanities and Social Studies at the National University of Ireland, Galway. 